
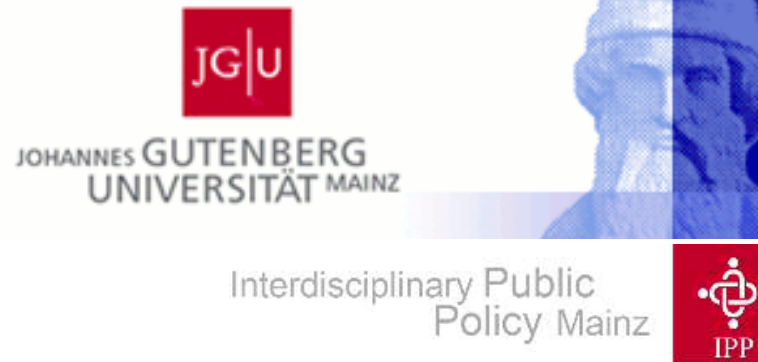

Gutenberg School of Management and Economics

\& Research Unit "Interdisciplinary Public Policy"

Discussion Paper Series

Why Rating Agencies Disagree on Sovereign

Ratings

Bernhard Bartels

December 2014

Discussion paper number 1416

Jakob-Welder-Weg 9

55128 Mainz

Germany

$\underline{\text { wiwi.uni-mainz.de }}$ 
Contact details

Bernhard Bartels

Department of Economics

Johannes-Gutenberg-Universität Mainz

Jakob-Welder-Weg 9

55128 Mainz

bartels@uni-mainz.de

All discussion papers can be downloaded from http://wiwi.uni-mainz.de/DP 


\title{
Why Rating Agencies Disagree on Sovereign Ratings*
}

\author{
Bernhard Bartels ${ }^{\dagger}$
}

December 2, 2014

\author{
Working Paper
}

\begin{abstract}
We empirically analyze why rating agencies disagree on countries' default risk. Specifically, we explore the sovereign ratings of four agencies and their interaction. Our results indicate that the frequency of split ratings and their lopsidedness is not related to their home region. We nevertheless find that rating agencies treat world regions differently. The Big Three rating agencies tend to follow each other predominantly in times of crises. The smaller European agency seems to be more independent but also more volatile in its rating behaviour.
\end{abstract}

JEL Classification: E62, F34

Keywords: Sovereign Risk, European Rating Agency, Rating Agencies

*I would like to thank Feri Rating and Research GmbH for the provision of their ratings. I have further benefited from helpful comments from Constantin Weiser, Thomas Apolte, Frank Smets, Isabel Schnabel, Philipp Harms, Beatrice Weder di Mauro and seminar participants of the Brown Bag Seminar, the 3rd IWH/INFER Workshop on Applied Economics and Economic Policy in Halle and the European Economic Association Annual Meeting in Toulouse.

${ }^{\dagger}$ Bernhard Bartels, Johannes Gutenberg-University Mainz, Economics Department, Jakob-Welder-Weg 4, 55128 Mainz, Email: bartels@uni-mainz.de 


\section{Introduction}

The recent financial crisis has evoked a revival of the discussion about the role of Credit Rating Agencies (CRAs). During the sovereign debt crisis in Europe, the so called Big Three rating agencies Standard \& Poor's, Moody's and Fitch Ratings started to downgrade several euro area economies and even assigned junk status to Ireland, Portugal and Greece. The sudden decline of trust in the solvency of European economies led many politicians to claim that the Big Three did either not realize the true credit risk or that their decisions were biased by political influence. ${ }^{1}$

Also, the academic literature has contributed to this debate: For instance, Gaertner et al. (2011) find that ratings in selected euro area economies between 2009 and 2010 ranked 2.3 notches below a hypothetical rating for a country outside the monetary union with the same economic fundamentals. Ferri et al. (1999) show that ratings have been pro-cyclical during the Asian crisis, thereby amplifying the recessions in affected countries. Add to this, empirical results by Fuchs and Gehring (2013) reveal that sovereign ratings are subject to a home bias. Comparing the behaviour of nine agencies, the authors find that cultural and economic ties of a respective agency's and its major stockholders' origin have a significant impact on a country's sovereign rating.

At the same time, the literature on determinants of sovereign credit ratings shows that large parts of the variation can be explained with few macroeconomic variables (see for instance Cantor and Packer (1996)). In a related panel analysis for sovereign ratings between 1995 and 2005, Afonso et al. (2011) find that their model (including a set of macroeconomic, political and regional variables) correctly predicts 75 percent of the ratings (within one notch variation) despite the fact that expectations for future economic development or other qualitative assessments are not taken into account by the respective agency.

Thus, empirical evidence towards the adequacy of sovereign ratings appears to be mixed: In general, ratings seem to quite well reflect the credit risk of a country, however, during times

\footnotetext{
${ }^{1}$ see Handelsblatt (January 17, 2012): "The myth of the U.S. conspiracy"
} 
Figure 1: Sovereign Credit Ratings during the Euro Crisis

The rating data have been retrieved from the four rating agencies whereby Feri uses a different rating scale but offers a translation Table of their 9-notch-scale to the 21-notch-scales of the Big Three. The red line illustrates the threshold between Investment and speculative grade status.
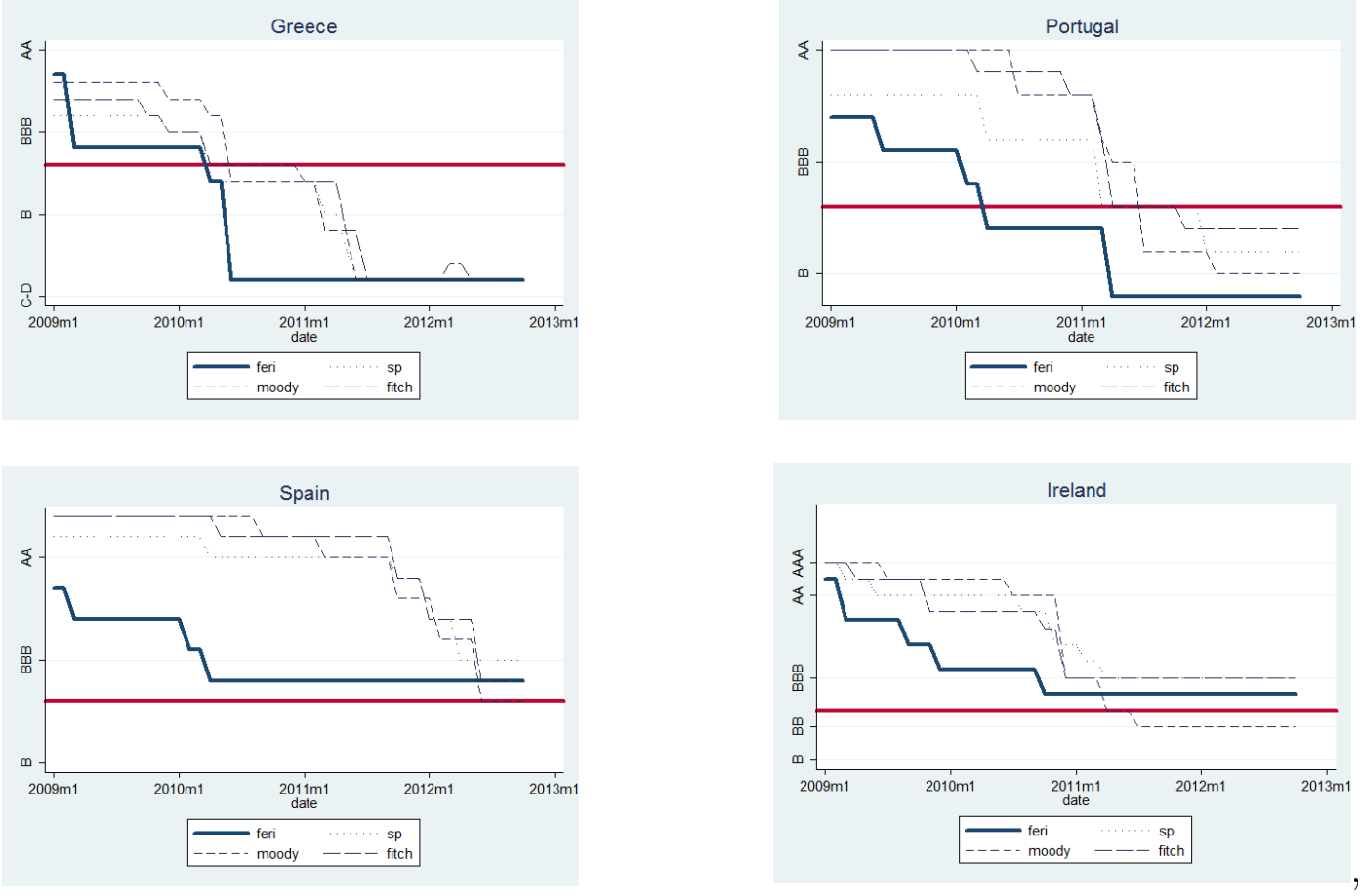

of crises, the Big Three have often been accused of reacting too late and to be overly bearish towards a country's creditworthiness. However, compared to the corporate sector it remains difficult to assess the adequacy of ratings since at least the advanced countries have not defaulted for many years. Therefore, we have to rely on indirect measures of performance such as the relative activity of rating agencies by studying follower-leader behaviour (Hill and Faff (2010)) or by comparing whether some regions systematically receive better ratings than others (Fuchs and Gehring (2013)).

Figure 1 illustrates the recent downgrades of euro area countries. Here, we observe that the Big Three decided almost unanimously on euro area ratings (besides Moody's downgrade for Ireland to speculative grade status). However, when adding the ratings from the smaller European rating agency, we observe that Feri has started to downgrade the same countries 
earlier and it assigned junk status to Portugal even one year before the Big Three took action. This observation raises the question how often rating agencies disagree on sovereign ratings and, even more important, what the reason for this disagreement might be.

In this paper, we intend to shed more light on this issue. We explore the determinants of sovereign split ratings across agencies and their propensity to be optimistic/pessimistic towards a country's credit risk (lopsided or symmetric ratings). Further, we evaluate whether the individual propensity to up- or downgrade a country's credit rating increases, following a previous rating change of a competetive agency in the same direction.

Our results indicate that split probabilities are not driven by a rating agency's home region but rather seem to be a consequence of the use of different rating models and uncertainty in the presence of adverse shocks. We also observe a different rating behaviour between the subscriber funded European agency and the Big Three which can be explained by the varying frequency of rating actions.

The paper is organized as follows: In section 2, we briefly review the related literature. Section 3 presents our data sample. In section 4, we show the results for political, macroeconomic and regional determinants of split ratings between the four agencies. In Section 5, we explore whether ratings are lopsided across agencies and analyze potential determinants of optimism and pessimism. Section 6 presents the results of up- and downgrade interaction between rating agencies before we conclude in section 7 .

\section{Literature Review}

In principle, one can distinguish between three types of explanations for split ratings:

First, splits are the consequence of uncertainty towards the true credit risk. Until now, the literature has only focused on banks (Morgan (2002)) and non-financial firms (Livingston et al. (2007)). They find that disagreement is not randomly distributed but that those companies with higher asset opaqueness are more likely to receive split ratings. To our knowledge, determinants of rating splits in the case of sovereigns have not been studied so far. However, 
looking at the frequency of rating splits (see section 2), it seems that rating agencies have different views on a country's default risk. These may be attributed to the use of different rating models or uncertainty in times of adverse shocks. For instance, one agency may put more weight on the default history and public debt ratio of a country whereas another primarily considers the economic well-being and political stability. Taking into account the empirical findings during times of crises, one may also contemplate whether the frequency of split ratings increases when a country is subject to adverse shocks.

Second, prior studies have discussed whether different business models among rating agencies can be a reason for split ratings. Using corporate bond ratings from 1999 to 2013 Bruno et al. (2013) find that a subscriber funded rating agency (Egan-Jones Rating Company) provides more rating updates than a rating agency that uses the issuer-pays model (Big Three agencies). This observation is robust to the registration of Egan-Jones as a National Recognized Statistical Rating Organization (NRSRO) in 2007. The authors conclude that the rating behaviour is thus driven by different business models (issuer-pays vs. subscriber funded). Bhattacharya et al. (2014) find that Egan-Jones provides not only more rating updates but also a higher rating quality suggesting that subscriber-funded agencies are even better suited to act in the best interest of investors. In case of sovereign ratings it is more difficult to measure the rating performance due to a lack of defaults. However, issuer-paid agencies may be acting in the home country's interest in order to keep their mandate whereas subscriber funded companies should be primarily interested in satisfying their customers. ${ }^{2}$

Third, split ratings can be the consequence of a rating agency's inclusion in regulatory frameworks. Many studies find that decisions by the Big Three have an impact on bond rates (Gaertner et al. (2011), Afonso et al. (2012), Alsakka and ap Gwilym (2010), Candelon et al. (2011)) and stock prices. That is to say, interest rates often follow rating decisions. ${ }^{3}$ One may suggest that a part of the causal relationship is driven by the quasi-automatic

\footnotetext{
${ }^{2}$ Only a limited number of the Big Three ratings are unsolicited (26.6\%). In our dataset, we find no significant difference across rating agencies between unsolicited and solicited ratings for one particular country.

${ }^{3}$ Some of those studies find that the relationship is bi-directional.
} 
impact on bond rates and stock prices via the inclusion of external ratings in regulatory frameworks: According to the Basel rules, institutional investors (pension funds, insurance companies etc.) are required to hold a fixed share of investment grade rated bonds in their portfolio. The decision of a rating agency to downgrade a country close to (or even to) junk status, might prompt investors to sell the respective bonds just to comply with the established rules. ${ }^{4}$ Consequently, if ratings are included in regulation, a respective CRA may have incentives to follow the decisions of other regulated competitors due to the expected effect of a rating change on interest rates.

Moreover, CRAs whose ratings are used by regulators may have incentives to be reluctant towards sovereign downgrades when they use sovereign ceiling policies which compel rating agencies not to assign a better rating to a firm than to the sovereign (Borensztein et al. (2013)). Adelino and Ferreira (2014) find that the downgrades of banks due to sovereign ceiling policies have significant negative effects on bank lending. This may lead rating agencies to be reluctant towards changes in sovereign credit risk. However, if one of the Big Three agencies takes the first step, competitors are incentivized to follow this decision due to expected repercussions on the country's credit risk. On the contrary, a smaller CRA has a higher degree of flexibility (it rates fewer big issuers like large banks and corporates (Bhattacharya et al. (2014))) and may thus have less concern to change a country's rating.

We contribute to the literature by exploring major determinants of split ratings for sovereigns across the four agencies. In particular, we investigate three hypotheses why split ratings for countries may exist:

(1) Split ratings for sovereigns can be explained by model uncertainty when rating agencies measure default risk differently, especially in the presence of large adverse shocks to credit risk.

(2) Conditional on the place of residence and the ownership, rating agencies assign better ratings to their home region (given the economic and political environment of countries).

\footnotetext{
${ }^{4}$ Investors do not necessarily rely on the rules of this standardized approach if they use the internal risk based approach (IRB).
} 
(3) The inclusion of ratings into regulatory frameworks leads to a more reluctant stance of the respective agency towards downgrades because it fears more far-reaching consequences than intended such as accompanying downgrades of bank ratings and rising interest rates. This in turn increases the tendency of agencies to follow competitors if these assign a downgrade previously.

\section{$3 \quad$ Data and Stylized Facts}

In this paper, we use monthly sovereign ratings from the Big Three rating agencies and from Feri AG, Germany's largest non-bank advisor/asset manager for private and institutional assets. $^{5}$

Exploring these data, we obtain a sample of 54 countries with monthly rating actions ranging from June 1999 to October 2012. The sample comprises 23 industrial countries and 31 emerging market economies and the total number of monthly observations for each rating agency is 9,016 (except for Fitch with 8,929 country-month observations). ${ }^{6}$ During our sample period of 13 years, we observe between 169 (Moody's) and 393 (Feri) rating changes. For robustness checks, we also consider watch and outlook decisions by the Big Three.

One part of the analysis will use annual data due to the fact that political and economic variables are only available on a yearly basis. The dataset entails 702 (except for Fitch with 695) rating observations by using end-of-year ratings in the analyses. As robustness checks, we also computed our results by using yearly rating averages.

We start by mapping the alphabetical notches into numerical values in order to perform statistical analyses. $^{7}$ A 17 maps the best rating (AAA or AAa) and a 1 the worst $(\mathrm{D} / \mathrm{D} / \mathrm{C})$. Therefore, lower values indicate a higher default probability. The Big Three ratings have 22 notches when using a linear scale. ${ }^{8}$ Feri uses 11 notches and provides a translation Table for

\footnotetext{
${ }^{5}$ see homepage of Feri AG at http://www.feri.de/en/company/portrait/

${ }^{6}$ see list of countries in Table 15 of the appendix

${ }^{7}$ see Table 16 in the appendix

${ }^{8}$ We follow Güttler and Wahrenburg (2007) and Afonso et al. (2011) in restricting the scale to 17 values since there are few observations in the lowest range
} 
comparison with the Big Three. We apply this transformation. ${ }^{9}$ The dividing line between investment grade and speculative grade on Feri's scale is between C and D, for S\&P and Fitch the dividing line is between BBB- and BB + and for Moody's it runs between the Baa3 and Ba1.

In order to compare rating differences across CRAs, the most convenient approach would be to use the transformation in Table 16. However, we cannot ensure that the values in the provided diagram by Feri are perfectly comparable. For instance, we are not able to verify that a letter $\mathrm{B}+$ on the Feri scale is comparable to the letter A on the Big Three scale. For that reason, we decided to classify the rating scales into broader categories as to ensure a better comparability. In the roughest classification we distinguish between three classes (see Table 1): First, we separate the best possible rating category (AAA) from those ratings considered as investment grade (while lower than AAA). The third category entails country-year observations with speculative grade ratings. In the authors' opinion, this approach has two advantages: First, we ensure that ratings are better comparable across agencies and second, the balanced number of ratings in each category enables us to exploit differences in the rating behaviour among industrialized countries (AAA/ investment grade) and emerging markets (investment grade/ speculative grade). A more segmented classification is provided in Table 17 of the appendix and has been used for our mean-comparison tests in section 5 .

Table 2 shows the absolute numbers of split ratings across the agencies. Here, all four agencies agreed in more than 50 percent of the sample $(396 / 702)$. Feri has relatively often disagreed with the ratings of the Big Three (200-300/702) whereas we observe a split across the Big Three only in every fifth case (105/702). The numbers remain broadly the same if we use yearly averages instead of year-end values and they indicate that Feri has more often deviated from the assessments of the Big Three than the latter to each other. Consequently, one might suggest that Feri's ratings are more independent compared to those by the Big

\footnotetext{
${ }^{9}$ see Feri press release on country ratings: http://frr.feri.de/files/documents/fer/press/2010-06-07_FER_ PM_0.pdf
} 
Table 1: Classification of Ratings

This Table summarizes annual observations of ratings across CRAs according to the three rating categories AAA/investment grade/speculative grade.

\begin{tabular}{lcccc}
\hline \hline & $\begin{array}{c}(1) \\
\text { S\&P }\end{array}$ & $\begin{array}{c}(2) \\
\text { Moody's }\end{array}$ & $\begin{array}{c}(3) \\
\text { Fitch }\end{array}$ & $\begin{array}{c}(4) \\
\text { Feri }\end{array}$ \\
\hline \hline AAA/Aaa/AAA & 179 & 191 & 169 & 142 \\
Investment Grade & 351 & 340 & 362 & 435 \\
& & & & \\
Speculative Grade & 172 & 191 & 164 & 125 \\
& & & & \\
Observations & $\mathbf{7 0 2}$ & $\mathbf{7 0 2}$ & $\mathbf{6 9 5}$ & $\mathbf{7 0 2}$ \\
\hline \hline
\end{tabular}

Table 2: Rating Splits across Rating Agencies

The numbers are based on the individual rating agencies' definitions. We only consider split ratings between AAA - investment grade and speculative grade status and use end-of-year ratings.

(1) (2) (3)

No-Split Split Feri Split Big3

\begin{tabular}{lccc} 
Standard \& Poor's & 396 & 236 & 105 \\
Moody's & 396 & 275 & 105 \\
& & & \\
Fitch Ratings & 396 & 239 & 105 \\
& & & \\
Feri & 396 & - & 306 \\
\hline \hline
\end{tabular}


Three. However, the results give no indication of whether the observed differences are regionspecific or randomely distributed. We will shed more light on this issue in the next section.

\section{Determinants of Split Ratings}

We now turn to show how often rating agencies disagree on a region's rating in order to find out whether some regions receive more splits than others. Table 3 provides an overview of the absolute number of rating splits across the three categories AAA/investment grade/speculative grade status. Two facts are worth mentioning:

Table 3: Split Ratings across Regions

This Table displays split ratings across selected regions. We differ between the three different rating classes according to Table 1. The industrialized Asian \& Pacific countries include Australia, New Zealand, Japan, Singapore and South Korea.

(1)

(3)

(4)

Feri S\&P Feri Moody Feri Fitch $\quad$ Split Big3 Observations

\begin{tabular}{|c|c|c|c|c|c|}
\hline EMU & 35 & 40 & 38 & 12 & 137 \\
\hline US/Canada & 7 & 8 & 6 & 3 & 39 \\
\hline Asia \& Pacific (ind.) & 17 & 28 & 18 & 33 & 65 \\
\hline Asia (emerg.) & 34 & 32 & 36 & 9 & 91 \\
\hline South America & 38 & 40 & 39 & 3 & 78 \\
\hline Eastern Europe & 67 & 72 & 66 & 20 & 169 \\
\hline
\end{tabular}

First, Feri disagrees more often on a rating across every region except the developed Asian \& Pacific countries. Thus, different opionions on credit risk are not restricted to specific areas. 
Also, disagreement does not seem to depend on a region's level of economic development. Second, we observe a higher frequency of split ratings across the Big Three in developed Asian $\&$ Pacific countries (50\% of the observations). One explanation for this result might be the distance between a rating agency's home region and the rated country. Still, the descriptive results may also be the consequence of country-specific characteristics. In the following, we will test whether the macroeconomic stance on the country level and the political environment have an influence on the disagreement across CRAs.

It is a generally accepted view that political risk determines the willingness to repay debt obligations whereas economic risk mirrors the country's ability to repay. Both variables are considered in the rating agencies' methodologies. By contrast, a country's business climate (protection of property rights, predictability of tax and legal regimes) is not necessarily related to the probability of sovereign debt repayment. ${ }^{10}$

The authors include the following two determinants of political uncertainty: (1) Political stability measures the probability of a government to be destabilized by unconstitutional or violent means. If political stability is endangered rating agencies may have different views on political developments within the country or on future governments. (2) Government effectiveness captures the ability of a government to provide public services, the degree of independence from political pressures and government credibility (Kaufmann et al. (2010)). If government effectiveness is low, rating agencies may face uncertainty with respect to the formal capacity of the government to service its debt.

We also use determinants for economic uncertainty: First, a higher (1) GDP per capita reduces the uncertainty towards a country's ability to repay its debt due to a large tax base. Second, a low ratio of (2) government debt to GDP reduces uncertainty as well as a low ratio of (3) external debt to imports. We also control for the (4) default history where a past default (after 1945) potentially increases uncertainty.

Finally, we include a measure for large adverse shocks to a country's default risk within a given year. If a country is subject to such a shock, we assume that rating agencies face a greater

\footnotetext{
${ }^{10}$ For details, we refer to the published methodologies of the CRAs
} 
uncertainty towards future country risk. In our model, we use the the Institutional Investor's country credit risk index which is based on a semi-annual survey among institutional investors and weighted by their exposure to sovereign risk. The variable is computed as the squared oneyear-change in credit risk whereby we only consider negative changes in credit risk. ${ }^{11}$ Thus, positive coefficients indicate that large adverse shocks to credit risk lead to higher uncertainty among rating agencies.

In the following, we carry out two seperate regressions and present the results. First, we restrict the sample to advanced economies and measure the probability to observe a split rating between $\mathrm{AAA}$ and below. In the second probit model, we measure the probability of split ratings in emerging economies at the threshold between investment and speculative grade status.

$$
\operatorname{Pr}\left(\operatorname{Split} A A A_{i j, t}\right)=F\left(\text { macro }_{k, t}, \text { region, } \Delta C C R_{k, t}\right)+e_{i j, t}
$$

and

$$
\operatorname{Pr}\left(\text { Split InvJunk }_{i j, t}\right)=F\left(\text { macro }_{k, t}, \text { region, default }_{k}, \Delta C C R_{k, t}\right)+e_{i j, t} .
$$

Table 4 provides the results obtained from the probit regression on AAA-level splits. Columns (1) and (2) present split results for Feri against the Big Three. Most importantly, we find no systematic increase in the split probability across regions. Higher government debt and a negative external balance increase the split probability whereby a lower value of government effectiveness leads to a decline. The latter result looks surprising, however, one may think of countries having a low probability to receive AAA-status by any agency if the index has not reached a certain upper threshold. The split probability increases significantly with a large decline in the Country Credit Rating. Indeed, this result confirms earlier findings in the literature stating that ratings are less reliable during times of crises (Ferri et al. (1999),

\footnotetext{
${ }^{11}$ Positive values are set equal to zero.
} 
Table 4: Split Ratings AAA vs. Non-AAA

This Table displays split probabilities for advanced economies at the threshold between AAA and below. We use a probit model with a dummy variable equal to one if two agencies disagree on the rating category (AAA/Non-AAA). Positive coefficients reflect an increase in the split probability, negative coefficients indicate a decrease. Standard errors are clustered on the country level.

\begin{tabular}{|c|c|c|c|c|}
\hline & $\begin{array}{c}(1) \\
\text { Split Feri-Big3 }\end{array}$ & $\begin{array}{c}(2) \\
\text { Split Feri-Big3 }\end{array}$ & $\begin{array}{c}(3) \\
\text { Split Big3 }\end{array}$ & $\begin{array}{c}(4) \\
\text { Split Big3 }\end{array}$ \\
\hline$\Delta$ CCR sq. & $\begin{array}{c}0.000533^{*} \\
(1.92)\end{array}$ & $\begin{array}{c}0.000847^{* * *} \\
(2.83)\end{array}$ & $\begin{array}{c}0.00105^{* * *} \\
(3.94)\end{array}$ & $\begin{array}{c}0.00134^{* * *} \\
\quad(4.10)\end{array}$ \\
\hline EMU & $\begin{array}{l}-0.110 \\
(-0.58)\end{array}$ & $\begin{array}{l}-0.0204 \\
(-0.14)\end{array}$ & $\begin{array}{l}-0.171 \\
(-1.15)\end{array}$ & $\begin{array}{l}-0.167 \\
(-1.23)\end{array}$ \\
\hline Asia \& Pacific & $\begin{array}{c}0.0975 \\
(0.46)\end{array}$ & $\begin{array}{l}0.206 \\
(1.59)\end{array}$ & $\begin{array}{l}0.176 \\
(1.27)\end{array}$ & $\begin{array}{c}0.179^{*} \\
(1.73)\end{array}$ \\
\hline USA \& Canada & $\begin{array}{l}-0.142 \\
(-0.60)\end{array}$ & $\begin{array}{l}-0.232 \\
(-1.27)\end{array}$ & $\begin{array}{l}-0.123 \\
(-0.89)\end{array}$ & $\begin{array}{l}-0.152 \\
(-1.16)\end{array}$ \\
\hline GDP per Capita & & $\begin{array}{c}0.00167 \\
(0.57)\end{array}$ & & $\begin{array}{c}-0.00385 \\
(-1.15)\end{array}$ \\
\hline Government Debt & & $\begin{array}{c}0.00176^{*} \\
(1.81)\end{array}$ & & $\begin{array}{c}0.000578 \\
(1.14)\end{array}$ \\
\hline Fiscal Balance & & $\begin{array}{c}-0.00213 \\
(-0.22)\end{array}$ & & $\begin{array}{c}-0.00565 \\
(-0.83)\end{array}$ \\
\hline External Balance & & $\begin{array}{c}-0.0302^{* * *} \\
(-4.47)\end{array}$ & & $\begin{array}{c}-0.0175^{* * *} \\
(-3.73)\end{array}$ \\
\hline GDP Growth & & $\begin{array}{c}0.00259 \\
(0.21)\end{array}$ & & $\begin{array}{c}0.00889 \\
(0.80)\end{array}$ \\
\hline Government Effectiveness & & $\begin{array}{c}0.651^{* * * *} \\
(4.70)\end{array}$ & & $\begin{array}{c}0.358 * * * \\
(3.79)\end{array}$ \\
\hline Political Stability & & $\begin{array}{c}0.0322 \\
(0.20) \\
\end{array}$ & & $\begin{array}{c}0.0934 \\
(0.78) \\
\end{array}$ \\
\hline Observations & 299 & 297 & 299 & 297 \\
\hline Pseudo $R^{2}$ & 0.025 & 0.189 & 0.138 & 0.283 \\
\hline
\end{tabular}

$t$ statistics in parentheses

$* \mathrm{p}<0.10, * * \mathrm{p}<0.05, * * * \mathrm{p}<0.01$ 
Table 5: Split Ratings Speculative vs. investment grade

This Table displays split probabilities for countries at the threshold between investment grade and junk status. We use a probit model with a dummy variable equal to one if two agencies disagree on the rating category (Inv. Grade/Junk). Positive coefficients reflect an increase in the split probability, negative coefficients indicate a decrease. Standard errors are clustered on the country level.

\begin{tabular}{|c|c|c|c|c|}
\hline & $\begin{array}{c}\text { (1) } \\
\text { Split Feri-Big3 }\end{array}$ & $\begin{array}{c}\text { (2) } \\
\text { Split Feri-Big3 }\end{array}$ & $\begin{array}{c}(3) \\
\text { Split Big3 }\end{array}$ & $\begin{array}{c}(4) \\
\text { Split Big3 }\end{array}$ \\
\hline$\Delta$ CCR sq. & $\begin{array}{c}-0.0000553 \\
(-0.14)\end{array}$ & $\begin{array}{c}-0.000897^{* * *} \\
(-2.63)\end{array}$ & $\begin{array}{c}0.0000973 \\
(0.55)\end{array}$ & $\begin{array}{c}-0.000226 \\
(-0.76)\end{array}$ \\
\hline Default History & $\begin{array}{l}0.137 \\
(1.22)\end{array}$ & $\begin{array}{c}-0.0360 \\
(-0.32)\end{array}$ & $\begin{array}{l}0.0252 \\
(0.66)\end{array}$ & $\begin{array}{c}-0.102^{* *} \\
(-2.28)\end{array}$ \\
\hline Eastern Europe & $\begin{array}{l}0.0796 \\
(0.44)\end{array}$ & $\begin{array}{l}0.0225 \\
(0.15)\end{array}$ & $\begin{array}{c}0.0179 \\
(0.32)\end{array}$ & $\begin{array}{r}0.0570 \\
(0.77)\end{array}$ \\
\hline Asia & $\begin{array}{l}0.127 \\
(0.60)\end{array}$ & $\begin{array}{l}-0.110 \\
(-0.71)\end{array}$ & $\begin{array}{c}0.00731 \\
(0.11)\end{array}$ & $\begin{array}{c}-0.0226 \\
(-0.33)\end{array}$ \\
\hline South America & $\begin{array}{l}0.185 \\
(0.93)\end{array}$ & $\begin{array}{l}-0.107 \\
(-0.65)\end{array}$ & $\begin{array}{c}-0.0611 \\
(-0.94)\end{array}$ & $\begin{array}{r}-0.0927 \\
(-1.09)\end{array}$ \\
\hline GDP per Capita & & $\begin{array}{r}-0.0181 \\
(-1.48)\end{array}$ & & $\begin{array}{c}0.00307 \\
(0.35)\end{array}$ \\
\hline Government Debt & & $\begin{array}{c}-0.000706 \\
(-0.29)\end{array}$ & & $\begin{array}{l}0.000970 \\
(0.69)\end{array}$ \\
\hline External Debt & & $\begin{array}{l}0.00166^{* *} \\
(2.28)\end{array}$ & & $\begin{array}{c}0.000206 \\
(0.55)\end{array}$ \\
\hline Fiscal Balance & & $\begin{array}{r}-0.0101 \\
(-0.74)\end{array}$ & & $\begin{array}{c}-0.00283 \\
(-0.48)\end{array}$ \\
\hline External Balance & & $\begin{array}{c}-0.00153 \\
(-0.19)\end{array}$ & & $\begin{array}{c}-0.000868 \\
(-0.26)\end{array}$ \\
\hline GDP Growth & & $\begin{array}{c}-0.00611 \\
(-0.69)\end{array}$ & & $\begin{array}{c}-0.00583 \\
(-1.27)\end{array}$ \\
\hline Government Effectiveness & & $\begin{array}{c}-0.299 * * \\
(-2.44)\end{array}$ & & $\begin{array}{c}-0.142^{*} \\
(-1.85)\end{array}$ \\
\hline Political Stability & & $\begin{array}{c}-0.0650 \\
(-0.90) \\
\end{array}$ & & $\begin{array}{c}0.0426 \\
(1.47) \\
\end{array}$ \\
\hline Observations & 403 & 284 & 403 & 284 \\
\hline Pseudo $R^{2}$ & 0.021 & 0.217 & 0.015 & 0.117 \\
\hline
\end{tabular}

$t$ statistics in parentheses

${ }^{*} \mathrm{p}<0.10,{ }^{* *} \mathrm{p}<0.05, * * * \mathrm{p}<0.01$ 
Gaertner et al. (2011)).

The split results for the Big Three in columns (3) and (4) are similar, however, we observe that the agencies disagree more often on ratings for Asian \& Pacific countries. ${ }^{12}$ In contrast to S\&P's and Moody's, Fitch has never assigned AAA-status to these countries. Also, the Big Three are often discordant on Japan's credit risk with S\&P's being the most pessimistic agency.

Taken together, the findings for splits on AAA-status do not suggest that countries in the euro area are particularly affected by split ratings whereas other regions are not. It seems that the frequency of disagreement increases only between the Big Three in the case of Asian \& Pacific countries, confirming our descriptive result in Table 3 .

Table 5 presents the results for splits between investment and speculative grade ratings. We find more split ratings between Feri and the Big Three in countries with high external debt and low levels of government effectiveness given. Again, we find no significant increase in the split probability across regions. In contrast to the results in Table 4, we find no positive effect of adverse shocks on the split probability. The coefficient is even negative and significant in column (2) suggesting that in the case of emerging markets, the agreement (to downgrade countries) among CRAs even increases. The Big Three disagree more often if countries have no default history and if the index of government effectiveness is low. We do not find an indication for the Big Three to disagree more often on country risk in one region than in another.

To sum up, our results suggest that disagreement among rating agencies stems either from the use of different rating models (external balance and debt ratios seem to have different weights) or from uncertainty during times of adverse shocks (only in advanced economies). We find that regional splits occur more frequently among the Big Three in Asian \& Pacific countries. In the following, we explore in which cases a CRA is more likely to be optimistic or pessimistic than its competitors.

\footnotetext{
${ }^{12}$ The Asian \& Pacific region includes Australia, New Zealand, Japan, Singapore and South Korea.
} 


\section{$5 \quad$ Are sovereign ratings lopsided?}

During the euro crisis, policy makers have expressed the expectation that a European based rating agency would publish a more unbiased view about European countries than rating agencies with headquarters in the U.S. Accordingly, one should expect that the U.S. based agencies assign better ratings to their immediate neighbours. Given the recent criticism by European politicians, we first examine rating differences in the euro area. The results are based on a study by Bartels and Weder di Mauro (2013).

Table 6: Mean comparison of ratings to the world

\begin{tabular}{|c|c|c|c|c|}
\hline Country Group & $\begin{array}{c}(1) \\
\text { Feri - S\&P }\end{array}$ & $\begin{array}{c}(2) \\
\text { Feri - Moody's }\end{array}$ & $\begin{array}{c}(3) \\
\text { Feri - Fitch }\end{array}$ & Observations \\
\hline \multicolumn{5}{|l|}{ 1999-2012 } \\
\hline $\begin{array}{l}\text { All Countries } \\
\text { industrialized Countries } \\
\text { Emerging Economies }\end{array}$ & $\begin{array}{l}0.18^{* * *} \\
-0.1 * * * \\
0.12^{* * *}\end{array}$ & $\begin{array}{c}0.12^{* * *} \\
-0.16^{* * *} \\
0.11^{* * *}\end{array}$ & $\begin{array}{c}0.19^{* * *} \\
-0.09 * * * \\
0.11^{* * *}\end{array}$ & $\begin{array}{l}702 \\
299 \\
403\end{array}$ \\
\hline \multicolumn{5}{|c|}{ Great Moderation (1999-2007) } \\
\hline $\begin{array}{l}\text { All Countries } \\
\text { industrialized Countries } \\
\text { Emerging Economies }\end{array}$ & $\begin{array}{l}0.36 * * * \\
0.02 \\
0.62^{* * *}\end{array}$ & $\begin{array}{c}0.33 * * * \\
-0.03 \\
0.60 * * *\end{array}$ & $\begin{array}{l}0.35 * * * \\
-0.02 \\
0.58 * * *\end{array}$ & $\begin{array}{l}486 \\
207 \\
279\end{array}$ \\
\hline \multicolumn{5}{|l|}{ Crisis Period (2008-2012) } \\
\hline $\begin{array}{l}\text { All Countries } \\
\text { Advanced Countries } \\
\text { Emerging Economies }\end{array}$ & $\begin{array}{l}-0.22^{* * *} \\
-0.37^{* * *} \\
-0.11^{* * *}\end{array}$ & $\begin{array}{l}-0.32 * * * \\
-0.46 * * * \\
-0.22 * * *\end{array}$ & $\begin{array}{c}-0.16^{* * *} \\
-0.34^{* * *} \\
-0.02\end{array}$ & $\begin{array}{c}216 \\
92 \\
124\end{array}$ \\
\hline
\end{tabular}

To begin, we investigate the rating differences in industrialized and emerging markets and on the euro area in particular. In Tables 6 and 7, we compute the mean comparisons of rating differences between Feri and the Big Three. The coefficients indicate that Feri has assigned more positive ratings to emerging markets (between 1999 to 2007) and has had a more pessimistic view on industrialized countries (only during the crisis). Within the euro area (Table 7), we observe no significant difference across the agencies during the Great Moderation, but a 
Table 7: Mean comparison of ratings in the euro area

Differences of the ratings are based on the transformation in Table 12; Positive coefficients indicate a better rating average compared to Feri; Significance levels of T-test are given as ***,**, and * representing $1 \%$, $5 \%$, and $10 \%$ respectively

\begin{tabular}{|c|c|c|c|c|}
\hline Rating Agencies & $\begin{array}{c}(1) \\
\text { Feri - S\&P }\end{array}$ & $\begin{array}{c}(2) \\
\text { Feri - Moody's } \\
\end{array}$ & $\begin{array}{c}(3) \\
\text { Feri - Fitch } \\
\end{array}$ & Observations \\
\hline \multicolumn{5}{|l|}{ 1999-2012 } \\
\hline euro area & $-0.18 * * *$ & $-0.31 * * *$ & $-0.25 * * *$ & 137 \\
\hline GIIPS & $-0.17^{* *}$ & $-0.38 * * *$ & $-0.25 * * *$ & 63 \\
\hline Non-GIIPS & $-0.22 * * *$ & $-0.11^{*}$ & $-0.26 * * *$ & 87 \\
\hline \multicolumn{5}{|c|}{ Great Moderation (1999-2007) } \\
\hline euro area & 0.03 & -0.09 & -0.08 & 89 \\
\hline$G I I P S$ & 0.05 & -0.12 & -0.09 & 43 \\
\hline Non-GIIPS & 0.02 & -0.07 & -0.07 & 46 \\
\hline \multicolumn{5}{|c|}{ Crisis Period (2008-2012) } \\
\hline euro area & $-0.58 * * *$ & $-0.71 * * *$ & $-0.56 * * *$ & 48 \\
\hline$G I I P S$ & $-0.65 * * *$ & $-0.95 * * *$ & $-0.6^{* * *}$ & 20 \\
\hline Non - GIIPS & $-0.54 * * *$ & $-0.54 * * *$ & $-0.54 * * *$ & 28 \\
\hline
\end{tabular}

strong decline in both euro area groups (GIIPS and non-GIIPS countries) between 2008-2012. These preliminary findings indicate that Feri tends to be more pro-cyclical in its rating behaviour than the Big Three and that compared to what could be expected it surprisingly perceives the entire euro area as a more risky asset. This result has not been described previously. On the contrary, Fuchs and Gehring (2013) find that rating agencies give preferential treatment to their home country. In the case of Feri, they also find a negative but insignificant effect for Germany. Also, the authors find only a small negative effect to the ratings of culturally more distant countries. In the case of the Big Three, they describe a positive home bias for S\&P's and Fitch.

In the following, we relate the rating decisions of a CRA to those of its competitors and distinguish whether optimism and pessimism are driven by economic fundamentals or by the belonging to a specific region. In contrast to Fuchs and Gehring (2013) we are also able to identify different rating behaviour when all rating agencies assign better ratings to a specific region than their individual rating models would predict. For instance, the authors show that 
all Big Three agencies assign better ratings to the U.S. than predicted. In our model, we focus on regions instead of single countries to increase the number of observations.

In Table 8, we summarize the number of months in which a CRA had a more pessimistic stance compared to all competitors across regions. In the case of Feri, we use the classification in Table 1 due to the different rating scales. The comparison among the Big Three is based on the scale of alphabetical notches. ${ }^{13}$ For instance, we consider a more pessimistic stance for Feri if the agency assigns investment grade whereas all Big Three agencies assign AAA-status. In case of the Big Three, we attribute a negative stance if one agency assign $\mathrm{B}+$ whereas another one assigns a B.

Our descriptive findings indicate that Feri is more often pessimistic towards credit risk in North America and Eastern Europe than its competitors. Standard \& Poor's takes the lead by having most often a pessimistic stance towards the euro area and emerging Asia whereas Moody's has a negative bias towards South America. Fitch Ratings has most often assigned lower ratings to the Asian \& Pacific region (industrialized).

The findings for optimism in Table 9 show that Feri assigns more often better ratings to emerging Asia and South America than the Big Three. Moody's has most often assigned better ratings to the EMU, North America, Asian \& Pacific economies and Eastern Europe. Taking the two tables together, three observations are worth mentioning: First, we find more volatility in ratings towards emerging markets than towards advanced economies (this confirms earlier findings). Second, the Big Three are more often optimistic towards advanced countries whereas Feri has more frequently assigned better ratings to the emerging world (except for Eastern Europe). Third, we observe that Moody's is the most often optimistic agency among the Big Three. The agency assigns more often better ratings in four of the six regions. It turns out that pessimism is more dispersed across agencies and regions.

Next, we include a set of macroeconomic variables following Cantor and Packer (1996) and

\footnotetext{
${ }^{13}$ This explains why disagreement with Feri is less frequent although the agency assigns more rating changes overall.
} 
Table 8: No. of Negative Deviations towards other CRAs

This Table displays country-month observations in which a rating agency has assigned lower ratings to specific regions than its competitors. Due to the different scales, we compare Feri's ratings with those of the Big Three along the pre-defined three rating categories whereas we use the full rating scale for the Big Three.

\begin{tabular}{lccccc}
\hline \hline & $\begin{array}{c}(1) \\
\text { Feri Pes. }\end{array}$ & $\begin{array}{c}(2) \\
\text { S\&P Pes. }\end{array}$ & $\begin{array}{c}(3) \\
\text { Moody Pes. }\end{array}$ & $\begin{array}{c}(4) \\
\text { Fitch Pes. }\end{array}$ & $\begin{array}{c}(5) \\
\text { Observations }\end{array}$ \\
\hline EMU & 235 & 296 & 92 & 111 & 1,738 \\
North America & 101 & 17 & 0 & 52 & 486 \\
Asia \& Pacific (industr.) & 12 & 99 & 74 & 136 & 810 \\
South America & 19 & 9 & 413 & 98 & 972 \\
Eastern Europe & 526 & 249 & 259 & 156 & 2,106 \\
Asia (em. markets) & 0 & 202 & 157 & 84 & 1,134 \\
\hline Observations & 893 & 872 & 995 & 637 & 7,246 \\
\hline \hline
\end{tabular}

Table 9: No. of Positive Deviations towards other CRAs

This Table displays country-month observations in which a rating agency has assigned higher ratings to specific regions than its competitors. Due to the different scales, we compare Feri's ratings with those of the Big Three along the pre-defined three rating categories whereas we use the full rating scale for the Big Three.

\begin{tabular}{lccccc}
\hline & $\begin{array}{c}(1) \\
\text { Feri Opt. }\end{array}$ & $\begin{array}{c}(2) \\
\text { S\&P Opt. }\end{array}$ & $\begin{array}{c}(3) \\
\text { Moody Opt. }\end{array}$ & $\begin{array}{c}(4) \\
\text { Fitch Opt. }\end{array}$ & $\begin{array}{c}(5) \\
\text { Observations }\end{array}$ \\
\hline EMU & 123 & 74 & 193 & 53 & 1,738 \\
North America & 0 & 12 & 98 & 0 & 486 \\
Asia \& Pacific (industr.) & 45 & 51 & 221 & 158 & 810 \\
South America & 418 & 159 & 29 & 118 & 972 \\
Eastern Europe & 181 & 302 & 733 & 133 & 2,106 \\
Asia (em. markets) & 364 & 88 & 87 & 228 & 1,134 \\
\hline Observations & 1131 & 686 & 1361 & 657 & 7,246 \\
\hline \hline
\end{tabular}


use a probit model to explain in which cases a rating agency shows a lower/higher probability to deviate from its competitors:

$$
\operatorname{Pr}\left(\text { pessimism }_{i j, t}\right)=F\left(\text { macro }_{k, t}, \text { region }_{\text {, default }}\right)+e_{i j, t} .
$$

and

$$
\operatorname{Pr}\left(\text { optimism }_{i j, t}\right)=F\left(\text { macro }_{k, t}, \text { region, } \text { default }_{k}\right)+e_{i j, t}
$$

Thereby, we can examine whether our descriptive findings hold when we control for countryspecific variation in the macroeconomic stance. North American countries are not taken into account due to the low overall disagreement across agencies. Table 10 presents the probit results for a negative rating bias. We find that Feri shows a higher probability to downgrade Eastern European countries and to assign lower ratings to countries with higher per capita income. S\&P's is more pessimistic on Eastern Europe and on EMU economies than the other Big Three. Moody's assigns more often negative ratings to South America, emerging Asia, countries with a default history and those with higher growth rates. The results for Fitch mirror our descriptive findings: We find no significant relation between the region and a higher frequency of stand-alone negative ratings. Here, we do not include the United States and Canada due to the lack of variation across agencies.

In Table 11, we show the probit results for a positive rating bias. Here, Feri is more generous to countries with large ratios of public debt and inflation. We do not find that a rating agency is characterized by marked optimism towards a specific region. This result stands in contrast to our descriptive findings when Feri often assigned more positive ratings to emerging markets than the Big Three. S\&P's has more often an optimistic view on South America, Eastern Europe and Asia. They also frequently assign better ratings to previous defaulters than the other Big Three agencies. Moody's is only more optimistic towards countries with higher public debt ratios whereas Fitch assigns better ratings to the industrialized Asian \& Pacific region and the euro area. 
Table 10: Probit Results for a Negative Bias

This Table displays the probit results for the probability to have a more pessimistic stance on a country's rating. The binary variable takes the value one in all years when the respective CRA assigns a lower rating (class) than competitors. Standard errors are clustered on the country level.

\begin{tabular}{|c|c|c|c|c|}
\hline & $\begin{array}{c}(1) \\
\text { Feri Neg. }\end{array}$ & $\begin{array}{c}(2) \\
\text { S\&P Neg. }\end{array}$ & $\begin{array}{c}(3) \\
\text { Moody Neg. }\end{array}$ & $\begin{array}{c}\text { (4) } \\
\text { Fitch Neg. }\end{array}$ \\
\hline GDP per Capita & $\begin{array}{c}0.00358^{* *} \\
(2.39)\end{array}$ & $\begin{array}{c}-0.00350^{* *} \\
(-2.08)\end{array}$ & $\begin{array}{c}-0.00501^{* * *} \\
(-2.73)\end{array}$ & $\begin{array}{c}-0.00127 \\
(-0.62)\end{array}$ \\
\hline Government Debt & $\begin{array}{c}-0.00212^{* *} \\
(-2.10)\end{array}$ & $\begin{array}{c}0.000729 \\
(1.26)\end{array}$ & $\begin{array}{c}-0.00114 \\
(-1.33)\end{array}$ & $\begin{array}{c}-0.000175 \\
(-0.24)\end{array}$ \\
\hline Fiscal Balance & $\begin{array}{l}0.000112 \\
(0.02)\end{array}$ & $\begin{array}{c}-0.00156 \\
(-0.35)\end{array}$ & $\begin{array}{c}-0.00315 \\
(-0.49)\end{array}$ & $\begin{array}{c}0.000132 \\
(0.03)\end{array}$ \\
\hline Inflation & $\begin{array}{c}-0.00439 \\
(-0.97)\end{array}$ & $\begin{array}{c}0.00364 \\
(1.37)\end{array}$ & $\begin{array}{c}0.00134 \\
(0.60)\end{array}$ & $\begin{array}{c}-0.00178 \\
(-0.70)\end{array}$ \\
\hline External Balance & $\begin{array}{c}-0.00569^{*} \\
(-1.88)\end{array}$ & $\begin{array}{c}0.00263 \\
(1.03)\end{array}$ & $\begin{array}{c}-0.000562 \\
(-0.22)\end{array}$ & $\begin{array}{c}0.000313 \\
(0.13)\end{array}$ \\
\hline GDP Growth & $\begin{array}{c}-0.0132^{* * * *} \\
(-3.34)\end{array}$ & $\begin{array}{c}-0.00250 \\
(-0.64)\end{array}$ & $\begin{array}{c}0.00499^{*} \\
(1.75)\end{array}$ & $\begin{array}{c}-0.00189 \\
(-0.43)\end{array}$ \\
\hline Industrialized & $\begin{array}{l}0.0498 \\
(0.64)\end{array}$ & $\begin{array}{c}0.136^{*} \\
(1.67)\end{array}$ & $\begin{array}{c}0.488^{* *} \\
(2.57)\end{array}$ & $\begin{array}{l}0.0219 \\
(0.28)\end{array}$ \\
\hline Default History & $\begin{array}{c}-0.0632 \\
(-1.05)\end{array}$ & $\begin{array}{c}-0.0173 \\
(-0.39)\end{array}$ & $\begin{array}{c}0.131 * * * \\
(3.05)\end{array}$ & $\begin{array}{c}-0.0574 \\
(-1.38)\end{array}$ \\
\hline EMU & $\begin{array}{c}0.0359 \\
(0.71)\end{array}$ & $\begin{array}{c}0.107^{* *} \\
(2.23)\end{array}$ & $\begin{array}{l}-0.119 \\
(-0.96)\end{array}$ & $\begin{array}{c}-0.0387 \\
(-0.59)\end{array}$ \\
\hline South America & $\begin{array}{c}0.00188 \\
(0.02)\end{array}$ & $\begin{array}{c}-0.0452 \\
(-0.58)\end{array}$ & $\begin{array}{c}0.359 * * * \\
(4.13)\end{array}$ & $\begin{array}{c}0.0308 \\
(0.40)\end{array}$ \\
\hline Eastern Europe & $\begin{array}{c}0.175^{* *} \\
(2.41)\end{array}$ & $\begin{array}{c}0.169^{* * *} \\
(2.72)\end{array}$ & $\begin{array}{c}0.190^{* *} \\
(2.21)\end{array}$ & $\begin{array}{c}-0.00802 \\
(-0.17)\end{array}$ \\
\hline Asia (em. markets) & & $\begin{array}{c}0.159^{* *} \\
(2.03)\end{array}$ & $\begin{array}{c}0.234^{* * *} \\
(2.63)\end{array}$ & $\begin{array}{c}-0.0274 \\
(-0.41)\end{array}$ \\
\hline Asia \& Pacific (industr.) & & $\begin{array}{r}0.0597 \\
(1.11)\end{array}$ & $\begin{array}{l}-0.118 \\
(-0.97)\end{array}$ & $\begin{array}{c}0.0356 \\
(0.42)\end{array}$ \\
\hline Observations & 681 & 681 & 681 & 681 \\
\hline Pseudo $R^{2}$ & 0.236 & 0.118 & 0.175 & 0.033 \\
\hline
\end{tabular}

$t$ statistics in parentheses

${ }^{*} \mathrm{p}<0.10,{ }^{* *} \mathrm{p}<0.05,{ }^{* * *} \mathrm{p}<0.01$ 
Table 11: Probit Results for a Positive Bias

This Table displays the probit results for the probability to have a more optimistic stance on a country's rating. The binary variable takes the value one in all years when the respective CRA assigns a higher rating (class) than competitors. Standard errors are clustered on the country level.

\begin{tabular}{|c|c|c|c|c|}
\hline & $\begin{array}{c}(1) \\
\text { Feri Pos. }\end{array}$ & $\begin{array}{c}(2) \\
\text { S\&P Pos. }\end{array}$ & $\begin{array}{c}(3) \\
\text { Moody Pos. }\end{array}$ & $\begin{array}{c}(4) \\
\text { Fitch Pos. }\end{array}$ \\
\hline GDP per Capita & $\begin{array}{c}-0.00992^{* * *} \\
(-3.00)\end{array}$ & $\begin{array}{c}-0.00216 \\
(-1.22)\end{array}$ & $\begin{array}{c}-0.00219 \\
(-0.90)\end{array}$ & $\begin{array}{c}-0.00545^{* *} \\
(-2.19)\end{array}$ \\
\hline Government Debt & $\begin{array}{c}0.00292^{* * *} \\
(3.24)\end{array}$ & $\begin{array}{c}0.000302 \\
(0.67)\end{array}$ & $\begin{array}{c}0.00128^{*} \\
(1.89)\end{array}$ & $\begin{array}{c}0.000351 \\
(0.86)\end{array}$ \\
\hline Fiscal Balance & $\begin{array}{c}0.00728 \\
(0.95)\end{array}$ & $\begin{array}{c}-0.00143 \\
(-0.28)\end{array}$ & $\begin{array}{c}-0.00553 \\
(-0.87)\end{array}$ & $\begin{array}{c}0.00502 \\
(1.13)\end{array}$ \\
\hline Inflation & $\begin{array}{c}0.00576^{*} \\
(1.79)\end{array}$ & $\begin{array}{c}-0.00110 \\
(-0.43)\end{array}$ & $\begin{array}{c}-0.00370 \\
(-0.71)\end{array}$ & $\begin{array}{c}0.00513^{* * *} \\
(2.82)\end{array}$ \\
\hline External Balance & $\begin{array}{c}0.00199 \\
(0.54)\end{array}$ & $\begin{array}{c}-0.00255 \\
(-0.97)\end{array}$ & $\begin{array}{c}-0.00864^{*} \\
(-1.75)\end{array}$ & $\begin{array}{c}-0.00257 \\
(-1.20)\end{array}$ \\
\hline GDP Growth & $\begin{array}{c}0.00736^{*} \\
(1.65)\end{array}$ & $\begin{array}{c}0.000687 \\
(0.27)\end{array}$ & $\begin{array}{c}-0.00494 \\
(-1.04)\end{array}$ & $\begin{array}{c}-0.00445 \\
(-1.60)\end{array}$ \\
\hline Industrialized & $\begin{array}{c}-0.0833 \\
(-0.71)\end{array}$ & $\begin{array}{l}0.148 \\
(1.63)\end{array}$ & $\begin{array}{c}-0.300^{* * *} \\
(-2.59)\end{array}$ & $\begin{array}{c}-0.00600 \\
(-0.08)\end{array}$ \\
\hline Default History & $\begin{array}{l}0.0784 \\
(1.48)\end{array}$ & $\begin{array}{c}0.111^{* *} \\
(2.31)\end{array}$ & $\begin{array}{c}-0.149^{* *} \\
(-2.17)\end{array}$ & $\begin{array}{c}0.0244 \\
(0.70)\end{array}$ \\
\hline EMU & $\begin{array}{c}0.174^{* * *} \\
(2.91)\end{array}$ & $\begin{array}{l}0.0343 \\
(0.65)\end{array}$ & $\begin{array}{c}-0.0674 \\
(-1.00)\end{array}$ & $\begin{array}{c}0.0776^{* *} \\
(2.34)\end{array}$ \\
\hline South America & $\begin{array}{l}0.0931 \\
(1.14)\end{array}$ & $\begin{array}{c}0.172^{* * *} \\
(2.64)\end{array}$ & $\begin{array}{c}-0.359^{* * *} \\
(-2.78)\end{array}$ & $\begin{array}{c}0.0404 \\
(0.79)\end{array}$ \\
\hline Eastern Europe & $\begin{array}{c}-0.0818 \\
(-0.93)\end{array}$ & $\begin{array}{c}0.165^{* *} \\
(2.50)\end{array}$ & $\begin{array}{c}-0.0394 \\
(-0.43)\end{array}$ & $\begin{array}{r}-0.0310 \\
(-0.52)\end{array}$ \\
\hline Asia (em. markets) & $\begin{array}{l}0.0237 \\
(0.27)\end{array}$ & $\begin{array}{c}0.142^{*} \\
(1.70)\end{array}$ & $\begin{array}{c}-0.316^{* * *} \\
(-3.42)\end{array}$ & $\begin{array}{c}0.0742 \\
(1.27)\end{array}$ \\
\hline Asia \& Pacific (industr.) & $\begin{array}{c}0.0674 \\
(0.56)\end{array}$ & $\begin{array}{c}0.0933 \\
(1.48)\end{array}$ & $\begin{array}{l}0.160 \\
(1.51)\end{array}$ & $\begin{array}{c}0.215^{* * *} \\
(3.72)\end{array}$ \\
\hline Observations & 681 & 681 & 681 & 681 \\
\hline Pseudo $R^{2}$ & 0.357 & 0.144 & 0.239 & 0.219 \\
\hline
\end{tabular}


Taken together, in contrast to widespread political presumptions our results do not point to the existence of a home bias across the four rating agencies. If anything, Eastern European countries receive more often lower ratings by Feri than by the Big Three and S\&P's assigns relatively low ratings to the euro area. South American countries are favoured by S\&P's and disadvantaged by Moody's. Overall, it seems that Feri assigns more often positive ratings to emerging markets (and less often negative ratings) whereas the Big Three are more often generous towards the advanced economies. Fitch seems to have a more neutral stance towards all regions except for the industrialized Asian \& Pacific countries.

\section{$6 \quad$ Rating Agency Interaction}

Previously, we have explained the behaviour of rating agencies by using economic, political or regional determinants. In this section, we take a closer look at the interaction between rating agencies. As we have seen before, Feri disagrees with the Big Three in almost every second case whereas the Big Three disagree with each other only in every fifth case (see Table 2).

Table 12: Number of Up- and Downgrades

This Table illustrates the total number of up- and downgrades across a sample of biannual rating observations across the four rating agencies. "Followers" indicate the share of observations when at least one of the competitors (excluding Feri) has changed its rating in the same direction during the previous six months.

\begin{tabular}{lcccc}
\hline \hline & $\begin{array}{c}(1) \\
\text { Feri }\end{array}$ & $\begin{array}{c}(2) \\
\text { S\&P }\end{array}$ & $\begin{array}{c}(3) \\
\text { Moody's }\end{array}$ & $\begin{array}{c}(4) \\
\text { Fitch }\end{array}$ \\
\hline \hline Upgrades & & & & \\
\% of "Followers" & $10 \%$ & $23 \%$ & $42 \%$ & $28 \%$ \\
\hline Downgrades & 175 & 78 & 48 & 73 \\
\% of "Followers" & $17 \%$ & $35 \%$ & $33 \%$ & $38 \%$ \\
\hline \hline
\end{tabular}


Bartels and Weder di Mauro (2013) and Hill and Faff (2010) have shown how often rating agencies take a lead in times of crisis and how often they followed another agency. ${ }^{14}$ In this paper, we explore whether it is possible to predict a rating agency's downgrade probability with an empirical model. We deliberately control for times of crises and focus on the rating behaviour in normal times. During times of crises CRAs have changed their ratings frequently which makes it hard to differentiate between pure interaction behaviour and common responses to crisis events such as a declaration of default.

Our reasoning during normal times is as follows: If one of the Big Three agencies decides to downgrade a country's rating by at least one notch, sovereign issuers face higher refinancing costs when investors begin to sell their positions or when they issue new bonds. Accordingly, competitors follow with subsequent downgrades as a lower rating increases sovereign risk by itself due to regulatory provisions such as the Basel capital regulation. The following behaviour is more pronounced for regulated agencies because they face higher costs of downgrades in the form of subsequent changes in bank ratings or rising interest rates in the economy. On the contrary, a smaller, less influential agency is not impeded by sovereign ceilings policy or other forms of unintended feedbacks.

In the following probit model we compute the probability of a negative/positive change in the rating within six months following the assignment of a lower rating by at least one other agency (lagged $D G$ / lagged $U G$ ). When considering downgrades, we control for the recent sovereign debt crises in emerging markets as well as the crises in the GIIPS economies. We also control for external credit risk shocks of common knowledge reflected by the semi-annual change in the Institutional Investor's Country Credit Rating (CCR). The inclusion of this variable helps to account for situations when rating agencies respond together to previously observable external shocks. Table 12 illustrates the number of up- and downgrades for each rating agency and shows the share of rating changes when a competitor has assigned a change

\footnotetext{
${ }^{14}$ This part extends an earlier study by Bartels and Weder di Mauro (2013) in which we provide a first descriptive analysis of leader/follower behaviour during selected crises in emerging markets and the euro area. Here, we extend the previous research by setting up a probit model which also includes potential interaction in normal times.
} 
Table 13: Downgrade interaction

This Table presents the probit results for downgrade interaction between rating agencies. The binary variable takes the value in all periods (bi-annual) if a rating agency assigns a downgrade to a country. The observations are restricted to those years in which at least one downgrade by at least one agency occurred. The lagged downgrade coefficients take the value one if a competitor has previously assigned a downgrade in the six months before and the agency under consideration has not.

\begin{tabular}{lc}
\hline \hline & $(1)$ \\
& DG Feri \\
\hline Feri follows S\&P & $-272^{* * *}$ \\
& $(-3.33)$ \\
& -0.0490 \\
Feri follows Moody & $(-0.50)$ \\
& $-0.308^{* * *}$ \\
Feri follows Fitch & $(-3.81)$
\end{tabular}

S\&P follows Moody

0.0563

(0.84)

S\&P follows Fitch

$0.109 * *$

(2.07)

Moody follows S\&P

0.0262

(0.77)

Moody follows Fitch

0.0300

(0.79)

Fitch follows S\&P

0.0587

(1.30)

Fitch follows Moody

0.0308

(0.49)

CCR Change

$-0.0117 * *$

$-0.0183 * * *$

$-0.00585 * *$

$-0.0142^{* * *}$

$(-2.12)$

$(-5.00)$

$(-2.06)$

$(-3.97)$

Emerging Market Crises

$0.111 \quad 0.283^{* *}$

$0.167^{* *}$

$0.263^{* *}$

(0.65)

(2.55)

(2.33)

(2.42)

\begin{tabular}{lcccc} 
GIIPS Crises & 0.117 & $0.201^{* * *}$ & $0.207^{* * *}$ & $0.155^{* * *}$ \\
& $(1.23)$ & $(3.98)$ & $(5.73)$ & $(2.97)$ \\
\hline Observations & 428 & 428 & 428 & 428 \\
Pseudo $R^{2}$ & 0.078 & 0.185 & 0.196 & 0.135 \\
Share of pred. DG $(\mathrm{p}>0.5)$ & 0.23 & 0.4 & 0.25 & 0.18 \\
\hline \hline
\end{tabular}

$t$ statistics in parentheses

${ }^{*} \mathrm{p}<0.10,{ }^{* *} \mathrm{p}<0.05,{ }^{* * *} \mathrm{p}<0.01$ 
Table 14: Upgrade interaction

This Table presents the probit results for upgrade interaction between rating agencies. The binary variable takes the value in all periods (bi-annual) if a rating agency assigns an upgrade to a country. The observations are restricted to those years in which at least one upgrade by at least one agency occurred. The lagged upgrade coefficients take the value one if a competitor has previously assigned an upgrade to the same country in the six months before and the agency under consideration has not.

\begin{tabular}{|c|c|c|c|c|}
\hline & $\begin{array}{c}(1) \\
\text { UG Feri }\end{array}$ & $\begin{array}{c}(2) \\
\text { UG S\&P }\end{array}$ & $\begin{array}{c}(3) \\
\text { UG Moody }\end{array}$ & $\begin{array}{c}(4) \\
\text { UG Fitch }\end{array}$ \\
\hline Feri follows S\&P & $\begin{array}{c}-0.203^{* * *} \\
(-3.93)\end{array}$ & & & \\
\hline Feri follows Moody & $\begin{array}{c}-0.167^{* * *} \\
(-3.01)\end{array}$ & & & \\
\hline Feri follows Fitch & $\begin{array}{c}-0.178^{* * *} \\
(-3.28)\end{array}$ & & & \\
\hline S\&P follows Moody & & $\begin{array}{c}0.0320 \\
(0.71)\end{array}$ & & \\
\hline S\&P follows Fitch & & $\begin{array}{c}0.139^{* * *} \\
(3.42)\end{array}$ & & \\
\hline Moody follows S\&P & & & $\begin{array}{c}-0.00677 \\
(-0.18)\end{array}$ & \\
\hline Moody follows Fitch & & & $\begin{array}{c}-0.00721 \\
(-0.19)\end{array}$ & \\
\hline Fitch follows S\&P & & & & $\begin{array}{c}0.131^{* * *} \\
(3.52)\end{array}$ \\
\hline Fitch follows Moody & & & & $\begin{array}{c}0.00292 \\
(0.06)\end{array}$ \\
\hline CCR Change & $\begin{array}{c}-0.00287 \\
(-0.63)\end{array}$ & $\begin{array}{c}0.00880^{* *} \\
(2.02)\end{array}$ & $\begin{array}{c}0.000473 \\
(0.12)\end{array}$ & $\begin{array}{c}0.0134^{* * *} \\
(3.03)\end{array}$ \\
\hline Observations & 628 & 628 & 628 & 628 \\
\hline Pseudo $R^{2}$ & 0.073 & 0.025 & 0.000 & 0.036 \\
\hline Share of pred. UG $(\mathrm{p}>0.5)$ & 0 & 0 & 0 & 0 \\
\hline
\end{tabular}

$t$ statistics in parentheses

${ }^{*} \mathrm{p}<0.10,{ }^{* *} \mathrm{p}<0.05,{ }^{* * *} \mathrm{p}<0.01$ 
in the same direction during the six previous months. These preliminary results show that the Big Three respond to each other in 23 to 42 percent of the change observations. Feri follows the Big Three less often which is probably due to its higher volatility. In the following, we test in three specifications for each agency whether the Big Three have a statistically significant propensity to follow each other. We also test in a fourth specification whether Feri responds to the Big Three.

$$
\operatorname{Pr}\left(\text { up }-/ \text { downgrade }_{i, t}\right)=F\left(\text { up }-/ \text { downgrade }_{j, t-1}, \operatorname{crisis}_{k, t}, \operatorname{ccr}_{k, t}\right)+e_{i, t}
$$

Table 13 presents the probit results for downgrade interaction across agencies. In the case of Feri (column (1)), we observe that Feri's downgrades are not related to the rating actions of the Big Three. On the contrary, our coefficients suggest that a downgrade by Feri is even less likely when the Big Three assigned a downgrade in the previous six months. Overall, the model is not able to predict Feri's downgrade probability. Even in times of crises in the GIIPS and in emerging markets, Feri does not assign more downgrades than usual.

In case of the Big Three, we observe that all interaction coefficients are positive. However, only the coefficient for S\&P following Fitch is significant. Besides, the Big Three show a higher probability to assign a downgrade in times of crises and after negative shocks to the Country Credit Rating. Yet, due to the small number of rating change observations in the overall sample, our model can only predict between 18 and 40 percent of the downgrades.

In Table 14, we present the results for upgrade interaction. We find that Feri assigns upgrades in a rather anti-cyclical fashion whereas $\mathrm{S} \& \mathrm{P}$ and Fitch have a higher degree of interaction. We also observe that positive shocks to the CCR increase the upgrade probability among two of the Big Three, however the coefficients are much smaller relative to those in the probit model for downgrade interaction. Add to this, the model does not predict the upgrade propensity of agencies at all which is in line with former theoretical and empirical studies which find that upgrades usually do not come as a surprise to market participants because they are based on 
public information (Hand et al. (1992), Boot et al. (2006)). Also, rating agencies should be less reluctant to assign upgrades since they are not constrained by sovereign ceiling policies.

To sum up, we observe that Feri seems to be more independent in its decisions to downgrade a country. The coefficients for Feri are even negative whereas we find positive and significant results for the Big Three. One explanation is that the smaller European agency uses a different rating model and that it is more independent than the Big Three. Second, it seems that following behaviour is more likely to occur during times of recessions rather than in times of economic booms.

\section{Conclusions}

The purpose of this paper is to investigate the question why rating agencies have different perceptions of country credit risk. After exploring the rating behavior of four agencies we find that belonging to a particular world region or the membership in the European Monetary Union neither leads to a higher split probability nor does it explain a rating if we control for other macroeconomic and political determinants.

Besides, the subscriber funded European agency Feri seems to have a stronger short-term focus (economic growth, fiscal balance, external balance) whereas the Big Three put more weight on long-term macroeconomic developments (GDP per capita, Government Debt). This can serve as an explanation why Feri tends to change its ratings more often than the Big Three. Our findings further suggest that sovereign ratings are not shaped by the origin or the language of the rating agency. Thus, the issuer-pays model does not constitute a conflict of interest for sovereign ratings. We argue that this is due to the fact that fees for sovereign ratings are relatively low compared to for instance structured finance products. Also, the agencies produce unsolicited ratings ${ }^{15}$. However, we find that CRAs use different rating models to assess a country's default risk. As we have stated above, our results suggest that Feri puts

\footnotetext{
${ }^{15}$ Feri produces only unsolicited ratings and the Big Three also have a share of $10-20 \%$ unsolicited ratings across all country groups and regions.
} 
more weight on short-term variables.

Finally, we have explored whether rating agencies respond to the actions of their competitors. Our probit results indicate that the Big Three have a higher propensity to follow each other than Feri. The descriptive results show that the Big Three follow each other in every third case on average while Feri tends to be more independent (10-17\% follower decisions). Also, the probit results support this finding with the follower coefficients even being negative and significant. The probit results for downgrades largely support the empirical findings whereas the upgrade results cannot be explained by following behavior. This result is related to earlier findings by Hand et al. (1992) who show that the impact of downgrades on markets is much stronger than the response of interest rates on upgrades. The authors conclude that downgrade decisions include more new information than upgrades.

One may conclude from this that the inclusion of sovereign ratings in regulatory frameworks puts large and influential agencies under pressure to be reluctant towards rating changes until one of the competitors starts to take action. We have shown that this behavior is especially pronounced in times of crises (in the euro area and in emerging markets) which might contribute to explain the pro-cyclical downgrades that we have seen in the past.

To conclude, our analysis does not support the notion that rating agencies have deliberately caused or at least aggravated the sovereign debt crisis in the euro area and might thus contribute to soothe concerns of European politicians. However, the inclusion in regulatory frameworks and the sheer size of agencies may have led to some unintended pro-cyclicality. Of course, we do not claim that the same applies to asset classes such as structured finance products or corporate bonds where the issuer-pays model is of much more importance. 


\section{References}

Adelino, M. and Ferreira, M. A. (2014). Bank ratings and lending supply: Evidence from sovereign downgrades. Working Paper presented at the 2014 NBER Credit Rating Agency Meeting.

Afonso, A., Furceri, D. and Gomes, P. (2012). Sovereign credit ratings and financial markets linkages: Application to european data. Journal of International Money and Finance, 31 (3), 606-638.

—, Gomes, P. and Rother, P. (2011). Short and long run determinants of sovereign debt credit ratings. International Journal of Finance $\&$ Economics, 16 (1), 1-15.

Alsakka, R. and AP Gwilym, O. (2010). Leads and lags in sovereign credit ratings. Journal of Banking \&3 Finance, 34 (11), 2614-2626.

Bartels, B. and Weder di Mauro, B. (2013). A rating agency for europe - a good idea? CEPR Discussion Paper, No. DP9512.

Bhattacharya, U., Wei, K. D. and XIA, H. (2014). Follow the money: Investor trading around investor-paid rating changes. Working Paper presented at the 2014 NBER Credit Rating Agency Meeting.

Boot, A. W., Milbourn, T. T. and Schmeits, A. (2006). Credit ratings as coordination mechanisms. Review of Financial Studies, 19(1) (02-058/2), 81-118.

Borensztein, E., Cowan, K. and Valenzuela, P. (2013). Sovereign ceilings "lite"? the impact of sovereign ratings on corporate ratings. Journal of Banking 86 Finance, 37 (11), $4014-4024$.

Bruno, V., Cornaggia, J. and Cornaggia, K. R. (2013). Does regulatory certification affect the information content of credit ratings? Available at SSRN 1962840. 
Candelon, B., Sy, A. N. R. and Arezki, R. (2011). Sovereign rating news and financial markets spillovers: Evidence from the european debt crisis. IMF Working Paper, (11/68).

CAntor, R. and PACker, F. (1996). Determinants and impact of sovereign credit ratings. Economic Policy Review, (Oct), 37-53.

Ferri, G., Liu, L.-G. and Stiglitz, J. E. (1999). The procyclical role of rating agencies: Evidence from the east asian crisis. Economic Notes, 28, 335-355.

Fuchs, A. and Gehring, K. (2013). The home bias in sovereign ratings. University of Heidelberg.

Gaertner, M., Griesbach, B. and Jung, F. (2011). Pigs or lambs? the european sovereign debt crisis and the role of rating agencies. International Advances in Economic Research, 17 (3), 288-299.

Güttler, A. and Wahrenburg, M. (2007). The adjustment of credit ratings in advance of defaults. Journal of Banking \& Finance, 31 (3), 751-767.

Hand, J. R. M., Holthausen, R. W. and Leftwich, R. W. (1992). The effect of bond rating agency announcements on bond and stock prices. Journal of Finance, 47 (2), 733-52.

Hill, P. and FAFF, R. (2010). The market impact of relative agency activity in the sovereign ratings market. Journal of Business Finance 83 Accounting, 37 (9-10), 1309-1347.

Kaufmann, D., Kraay, A. and Mastruzzi, M. (2010). The worldwide governance indicators - methodology and analytical issues. The World Bank Policy Research Working Paper, WP5430, 1-29.

Livingston, M., Naranjo, A. and Zhou, L. (2007). Asset opaqueness and split bond ratings. Financial Management, 36 (3), 49-62.

Morgan, D. P. (2002). Rating banks: Risk and uncertainty in an opaque industry. American Economic Review, 92 (4), 874-888. 


\section{A Tables}

Table 15: Country Table 1999-2012

\begin{tabular}{|c|c|c|}
\hline Country Group & $\begin{array}{c}(1) \\
\text { Advanced Countries }\end{array}$ & $\begin{array}{c}(2) \\
\text { Emerging Countries }\end{array}$ \\
\hline & $\begin{array}{c}\text { Australia } \\
\text { Austria } \\
\text { Belgium } \\
\text { Canada } \\
\text { Denmark } \\
\text { Finland } \\
\text { France } \\
\text { Germany } \\
\text { Greece } \\
\text { Ireland } \\
\text { Italy } \\
\text { Japan } \\
\text { Netherlands } \\
\text { New Zealand } \\
\text { Norway } \\
\text { Portugal } \\
\text { Singapore } \\
\text { South Korea } \\
\text { Spain } \\
\text { Sweden } \\
\text { Switzerland } \\
\text { U.K. } \\
\text { U.S. }\end{array}$ & $\begin{array}{c}\text { Argentina } \\
\text { Brazil } \\
\text { Bulgaria } \\
\text { Chile } \\
\text { China } \\
\text { Colombia } \\
\text { Croatia } \\
\text { Czech Republic } \\
\text { Egypt } \\
\text { Estonia } \\
\text { Hungary } \\
\text { India } \\
\text { Indonesia } \\
\text { Israel } \\
\text { Latvia } \\
\text { Lithuania } \\
\text { Malaysia } \\
\text { Mexico } \\
\text { Peru } \\
\text { Philippines } \\
\text { Poland } \\
\text { Romania } \\
\text { Russia } \\
\text { Slovakia } \\
\text { Slovenia } \\
\text { South Africa } \\
\text { Thailand } \\
\text { Turkey } \\
\text { Ukraine } \\
\text { Venezuela } \\
\text { Vietnam }\end{array}$ \\
\hline
\end{tabular}

classification according to the IMF definition 
Table 16: Rating Transformation

\begin{tabular}{cccc}
\hline \hline (1) & $(2)$ & $(3)$ & $(4)$ \\
Rating Notation & Feri & S\&P/Fitch & Moody's \\
\hline \hline AAA/AAA/AAa & 9 & 17 & 17 \\
\hline AA/AA+/Aa1 & 8 & 16 & 16 \\
AA/AA/Aa2 & 8 & 15 & 15 \\
A/AA-/Aa3 & 7 & 14 & 14 \\
B+/A+/A1 & 6 & 13 & 13 \\
B+/A/A2 & 6 & 12 & 12 \\
B/A-/A3 & 5 & 11 & 11 \\
C/BBB+/Baa1 & 4 & 10 & 10 \\
C/BBB/Baa2 & 4 & 9 & 9 \\
C/BBB-/Baa3 & 4 & 8 & 8 \\
\hline D/BB+/Ba1 & 3 & 7 & 7 \\
D/BB/Ba2 & 3 & 6 & 6 \\
D/BB-/Ba3 & 3 & 5 & 5 \\
D-/B+/B1 & 2 & 4 & 4 \\
D-/B/B2 & 2 & 3 & 3 \\
D-/B-/B3 & 2 & 2 & 2 \\
E/CCC+/Caa1 & 1 & 1 & 1 \\
E/CCC/Caa2 & 1 & 1 & 1 \\
E/CCC-/Caa3 & 1 & 1 & 1 \\
E-/CC/Ca & 1 & 1 & 1 \\
E-/C/Ca & 1 & 1 & 1 \\
Default/Default/C & 1 & 1 & 1 \\
\hline \hline Rating & & \\
\hline
\end{tabular}

Rating transformation based on the Feri translation Table

Sources: Feri Rating GmbH, Standard \& Poor's, Moody's, Fitch 
Table 17: Classification of Ratings

\begin{tabular}{|c|c|c|c|c|}
\hline & $\begin{array}{c}(1) \\
S \& P\end{array}$ & $\begin{array}{c}(2) \\
\text { Mooody's }\end{array}$ & $\begin{array}{c}(3) \\
\text { Fitch }\end{array}$ & $\begin{array}{l}\text { (4) } \\
\text { Feri }\end{array}$ \\
\hline$A A A / A a a / A A A$ & 179 & 191 & 169 & 142 \\
\hline$A A / A a / A A$ & 95 & 89 & 104 & 118 \\
\hline$A / A / A-B$ & 122 & 129 & 117 & 145 \\
\hline$B B B / B a a / C$ & 134 & 122 & 141 & 172 \\
\hline$B B / B a / D$ & 113 & 112 & 110 & 52 \\
\hline$B / B / D-$ & 43 & 50 & 43 & 34 \\
\hline$C C C-D / C a a-D / E-E-$ & 16 & 8 & 11 & 39 \\
\hline
\end{tabular}


Table 18: Descriptive Statistics

\begin{tabular}{lcccc}
\hline \hline & $\begin{array}{c}(1) \\
\text { Overall Sample }\end{array}$ & $\begin{array}{c}(2) \\
\text { Non-Split }\end{array}$ & $\begin{array}{c}(3) \\
\text { Split Feri-Big3 }\end{array}$ & $\begin{array}{c}(4) \\
\text { Split Big3 }\end{array}$ \\
\hline \hline GDP per Capita & 19.000 & 27.205 & 14.265 & 15.848 \\
Government Debt & 52.6 & 58.8 & 48.3 & 50.8 \\
External Debt & 64.2 & 36.1 & 84.7 & 73.2 \\
Political Stability & 0.92 & 1.04 & 0.98 & 0.69 \\
Government Effectiveness & 0.82 & 1.18 & 0.6 & 0.72 \\
$\Delta$ Country Credit Rating (CCR) & 4.58 & 4.17 & 5.12 & 5.02 \\
Default History & 221 & 47 & 100 & 74 \\
European Monetary Union & 137 & 63 & 51 & 23 \\
\hline \hline
\end{tabular}

